\title{
Ubiquitous Learning in Appropriate Learning Environments
}

\author{
Merja Meriläinen, Maarika Piispanen \\ Kokkola University Consortium Chydenius, Finland
}

\begin{abstract}
The changing society sets teacher training, its learning environments and teacher's challenges, which require transforming the operational cultures and broadening the ways, that learning environments are seen and understood. Change in the operational culture requires, above all, the teachers to function and network in new ways to achieve a new kind of understanding and internalization of learning environments and pedagogy. Pedagogical development is primarily important as the concepts of learning, essential information, education and world are rapidly changing. Study modules that are based on new kinds of pedagogical models increase the accessibility of university studies and give individuals better possibilities for lifelong learning. Class teachers' adult education is developing learning environments with emphasis on $e$ learning. Adult students' life situations pose challenges to full-time attendance, and this has been seen as a possibility to develop class teacher educators' pedagogical abilities in planning, developing, and using transformational e-learning methods and new pedagogical models. The 25 years of class teachers' adult education has been based on the students' physical attendance. Now, taking into consideration the students' needs and hopes, we are developing 'distance attendance' alternatives for physical attendance.

In this article we describe a blended learning study module that was carried out in class teachers' adult education. It offered the students versatile, unique, individual and communal possibilities to fully study in authentic contextual environments, exploiting virtual tools. The goal of the planning of this module was to create a learning environment that would give a student an optimal learning experience (Creative Work Flows for Learning) in versatile, authentic, e-learning environments. In the study, the ubiquitous learning model was tried out in a 6 credits' study module for class teachers' adult education that was based on the principles of transformational pedagogy $(O E D)$. The module was carried out in flexible and versatile learning environments based on transformational pedagogy, where knowledge also included command of the 21 st century teaching
\end{abstract}

skills 21. [27] The theoretical framework of the study module followed the model of contextualpedagogical model [22]. The study module, that was based on a strong pedagogical ground, offered the students a possibility to not only choose a suitable time for studying, but also to acquire transversal competences which are linked to transformational pedagogy, as a part of an authentic learning experience.

\section{Introduction}

Digitalization challenges traditional qualification structures and hierarchies. Competition in educational market is increasingly global as top universities offer free online lectures anyone can watch at home. The relationship between physical participation and distance learning is an essential question of attractive education today. Honkonen [11] urges education providers to think when it is useful to bring people physically together and when a well-planned virtual connection is enough. Crucial is, which makes a better learning context.

The researchers of virtual education have noticed that although educators know what the elements of an active learning process are, those elements are not always applied in teaching [14]; [23]; [31] Hodges and Repman [31] state that in university teaching, the learning environments of virtual courses are rather information channels built around technology than virtual learning environments based on methods that enhance and enable authentic learning. Studies show that learning environments that utilize technology in versatile ways and thus make it possible to act in authentic real-life learning contexts are seen as a possibility for developing teaching.

Several studies in the field of training and education show that there is a need for pedagogical change, and that the change should be towards a transformational learning environment [22] [25]. Transformational pedagogy demands the teacher to be open to growth and development, and to acknowledge that learning spaces and situations have expanded away from the traditional, time- and place-bound, learning and schools [22]. Cavallo, Stager and Papert [4] have stated that we cannot 
consider academic learning and our emotional side as two separate parts. This should be equally true for teachers as well as pupils: the world that we carry within us outside school is with us also at school - therefore we should see and understand the ways the society works and combine it with pupils' abilities and creativity. From the point of view of the transformational school, the transformational view of school and learning also creates a better basis for teachers to repeatedly get enthusiastic about the possibilities of pupils and learning environments, instead of seeing their constraints. [7]

In this research project, the starting point was to offer class teacher students a possibility to do a sixcredits' study module (Comprehensively towards context and experience-based learning) utilizing the possibilities of modern e-learning in a versatile way. The project included planning and carrying out a learning process that was linked to authentic learning contexts and utilized virtual possibilities and e-pedagogy innovatively. The virtual possibilities enabled expanding the learning environment into informal and authentic learning contexts. The study unit Overall towards contextual and experiential learning challenged students to create ideal $21^{\text {st }}$ Century learning environments based on Finnish National Core Curriculum [2]. This pilot course acted as a tool for renewing adult teacher education program to adapt it to answer future demands.

The data was collected during the six ECTS study unit in spring 2015. The data consists of:

- Real time seminars

- Recorded professional discussions

- Practicum evaluation reports

- Learning diaries

- Peer assessments

The main study method was Qualitative Analysis of the content, which according to Mayring [21] describes to be an approach of empirical, methodological controlled analysis of texts within their context of communication, following content analytic rules and step-by-step models, without rash quantification. The hermeneutic circle will interact between the research documentation, theory and the interpretation of the researcher.

The study module was based on socio-cultural and situational views of learning, as well as transformational e-learning pedagogy. According to Hodges et al. [9] planning and carrying out pedagogically appropriate learning environments especially for e -learning was seen as the most important objective of the project. The study module was carried out as an intervention and its objective was also to give the students a model for working and learning in authentic learning environments, and developing transversal competences. This learning environment can easily be transferred to different learning contexts also in basic education, where the students will later be working.

\section{Comprehensively towards context and experience-based learning}

The world has changed and as educators we should admit that so have students and studying. The choices we make as regards learning environments and pedagogy should be guided by learners' experiences and approaches. [25] We approached the planning process from the contextual-pedagogical framework [22], [27], [26] which guided towards authentic learning as described by Herrington, Reeves and Oliver [30]. Here, authentic learning is seen as an approach which links together real-life strategies and learning and education that utilize e-learning. Authenticity also means planning such learning environments, situations and processes that give the learner a possibility to think and act like professionals and experts. Authentic learning tasks were central in the planning of this study module and, as Purser, Towndrow \& Arangui [29] state, planning and choosing authentic learning tasks has a great influence on the quality of education. This is true whether the implementation of the virtual study module is traditional or follows the latest trends, as in this research project.

In this research project, the objectives of the study module - to perceive basic education curriculum from the point of view of interdisciplinary integration; to expand one's comprehension of learning environments to include versatile contextual environments; to apply innovative teaching methods in the planning and implementation of teaching - invited to implement the module from the starting points of transformational pedagogy. They also challenge us teacher educators to expand our views of learning environments and to apply innovative teaching methods in the planning and implementation of an e-learning environment.

The Finnish national core curriculum for basic education [6] gives a possibility to integrate subjects as well as create cross-curricular themes. According to the curriculum [6], the objective of integrating instruction is to guide pupil in examining phenomena from the perspectives of different fields of knowledge, thereby elaborating themes and emphasizing general educational goals. Though the curriculum clearly gives a possibility to integrate subjects, teaching and learning is still generally based on specific subject knowledge in Finnish schools. The Finnish National Board of Education have just finished curriculum renewing process, where principles of planning the core 
curriculum according to Halinen [6] are considered for following perspectives: building on strengths, sustainable future as an objective, equality in all areas of education, meeting pupils' needs and supporting wellbeing and other prerequisites for learning, coherence and consistency of basic education, learning continuums and international aspects.

During the Overall towards contextual and experiential learning - course students are guided through the planning process by supporting them to create enthusiastic, authentic learning environments, familiar to children, in connection to real life with learning tasks similar to life outside the school. Students themselves go through and experience the whole process in a "pupil" role where the learning expresses complete learning process in Contextual pedagogical learning and consists of all its elements as seen in Table 1.

Table 1. The key features in Contextualpedagogical learning

\section{Key features in theory \\ REAL LIFE PHENOMENON -EMPHASIS ON SKILLS AND UNDERSTANDING}

Key features in practice Your group has been chosen to an innovative project competition! It is starting NOW!

Key features in theory

AUTHENTIC LEARNING TASK -RISES FROM THE PHENOMENON

Key features in practice Your task is to plan and implement a contextual and memorable production that is based on curriculum from interdisciplinary point of view. Target group primary school children.

Key features in theory

\section{ENTHUSIASTIC LEARNING PROCESS}

Key features in practice "Be creative -look to the curriculum through authentic, everyday phenomena -suitable for children certain age, enthusiastic and functional." Could your PopUp! -school be Children's' University, A Day in a Circus, Flee Market, Fishing Trip... Or something else that happens in real life?

Key features in theory

\section{AUTHENTIC TASKS, WHICH REMINDS REAL LIFE WAYS TO WORK}

Key features in practice Detailed project plan to support long-lasting planning and developing selfdirecting skills. "Your project will culminate on May around the city/ woods/ seaside as a PopUp! -school day together with primary school children. Be prepared and good luck!"

\section{Key features in theory INTERDISCIPLINARY CURRICULUM \\ USE \\ OF}

Key features in practice "Look through curriculum and make curriculum contents to fit to curriculum learning aims in your project. Fade out disciplines and make the blend interdisciplinary visible."

Key features in theory

TEACHERS ROLE -21 ${ }^{\text {ST }}$ CENTURY CIVIL SKILLS PEDAGOGICAL CONTENT KNOWLEDGE EXPERT

Key features in practice "Make your learning visible in your personal learning environment (use blog, web pages, presentation tools, recordings, Pitching...) Combine theory to practice -read articles, discuss and share your thoughts."

Key features in theory

ASSESSMENT IS A TOOL FOR LEARING, VISIBLE AND KNOWN FROM THE BEGINNING OF THE PROCESS

Key features in practice Competence based curriculum will create a framework to assessment -students are able to target individual learning to assessment criteria from the beginning of the learning process.

Rather than just adjust one element of the learning environment at a time, this six ECTS-learning expresses holistic way to experience, learn and understand transformational pedagogic in authentic learning process [4] in a radically different environment not just for this particular setting, but for any setting. The whole study course expresses interdisciplinary curriculum implementing, open, learner-centered, project-based way to study and combine theory and practice, investigating and implementing learning of students' own choice and learning through design and construction.

Piispanen [27] highlights that in the contextualpedagogical approach both pedagogy and learning context are seen meaningful to each other; they are planned so that they support one another, utilize the students' experiences and knowledge, and stimulate several senses. This meaning is especially linked to allowing room for the student, his experiences, knowledge, and ways of learning. Leppisaari, Meriläinen, Piispanen and Pulkkinen [19] note that acquiring future metaskills requires also new teaching methods. This means that pedagogical models and methods, rich and authentic contents and teaching materials should be paid special attention to in education. According to Leppisaari [16], e-learning is changing as learner-centered and communal learning environments challenge prevailing views of learning. 
According to studies [13], [33] the approach of authentic learning, rising from the idea of situational learning, can help to find pedagogical solutions that support the acquirement of $21 \mathrm{st}$ century skills. A national assessment of online education, made by the Finnish Higher Education Evaluation Council (FINHEEC), showed that there is a need to increase authenticity of online education of universities of applied sciences [18]. In the same way, authenticity is a central development area also in the planning and implementation of e-learning environments in Class teacher adult education. This point of view guided the development work of the study module presented in this article.

The decision to change the implementation of instruction of an existing study module entirely form contact instruction to distance learning was rather thought-provoking among the teachers. However, central and important was that the planning would be guided by pedagogically legitimate teaching arrangements and an inspiring e-learning environment that would enable the students to reach the objectives of the study module and to use their competencies and strengths. It was also important to follow the principles of authentic learning. When we were planning the study module, the teachers' topics of conversation were pedagogy and learning environments, whereas matters related to technology were clearly not a point of concern. Also Puentedura's [28] SAMR model includes this insight to the relationship between learning tasks and technology in planning learning processes that utilize technology. According to Puentedura [24], in learning environments that make use of technology, the nature of the learning task either stays the same while the media that is used change, or the learning tasks are refined and change because of the possibilities provided by technology. This was also the case in the study module discussed in this article.

- In the end, if you really think about it, is it anything more than creating a pedagogically suitable learning environment? -That's right, the same questions guide the planning process in contact teaching and distance teaching, because the idea of learning does not change even if the learning environment changes. -That's it! Somehow I cannot help thinking how we will get Ida to participate in this, I have to remind myself not to fall into that kind of thinking! -Now, let's challenge ourselves and plan an inspiring learning environment that enables reaching the objectives of the study module in a way that is motivating and makes use of students' knowledge, skills, and strengths.
According to Impiö, Meriläinen and Piispanen [9], in planning an e-learning environment crucial to learning is not where the students are and when they are there. Instead, important is how learning and reaching the objectives is enabled independent of time and place, making use of students' competencies and the knowledge of people's ways in everyday life [12]. This view is supported by Bonk, Kim and Zheng's [3] study, according to which strengthening the possibilities of authentic learning requires teaching and working methods that are compatible with real professional situations and expertise, and thus utilizes the possibilities that virtual teaching and the development of educational technology offer.

The framework for the e-learning environment discussed in this article is the contextualpedagogical approach to planning and implementing teaching. According to Piispanen and Meriläinen [26], it is based on comprehensive and transversal pedagogical knowledge, the learner having a central role in processing and building information. The researchers [26] emphasize that learning happens in active interaction with the environment, the learner taking the role of an authentic actor and building new information with others using real-life working methods.

Congratulations! Your group has been chosen to a Project planning competition that starts right NOW! Your task is to plan and implement a contextual, experienceful PRODUCTION on the basis of Basic education curriculum and interdisciplinary integration. The culmination of the production will take place in May as an experienceful POP UP School Day around Finland in cooperation with local businesses.

When the phenomenon, the topic of learning, is taken from real world, the working methods follow those of real life and engage the students to the task that is implemented in an authentic situation [3]. As a pedagogical model the contextual-phenomenal learning means using learning tasks that challenge students to solve problems and think as professionals of a certain field. The starting point of this try-out study module was to implement cognitively realistic learning tasks in ubiquitous learning environments that made use of the possibilities of e-learning.

The central questions in planning the try-out module were rather usual in all planning of teaching: What is good pedagogy? Where does learning best take place? What kind of information is needed in order to gain new understanding? How to motivate and inspire students to find and organize information? How to process, structure and shape information into new information? What are the roles of the teacher and the student in the 
learning situation? In addition to these, we had to ponder how to carry out the learning environment in the contextual-pedagogical framework and enable authentic learning in ubiquitous learning environments.

In the study module Comprehensively towards contextual and experience-based learning, the students were supported and encouraged to plan phenomenon-based, authentic, and experienceful learning wholes for, and together with, basic education pupils. The learning wholes were implemented in schools chosen by the students in different parts of Finland.

In the study module the students went through a contextual-pedagogical learning process phase by phase in learner's role. During the process they planned and implemented a contextual-pedagogical learning process with a class of pupils, following the principles and methods of project work.

According to Rule [32], authenticity in learning includes an inquiry-based approach that supports the acquisition of thinking and metacognitive skills, and increases discourse within a community of learners, and the learner's choice.

The learning environment thus plays an important part in a successful e-learning experience. Therefore, planning a learning whole must be guided by pedagogy, and working methods must be chosen so that they support it. Lombardi [24] points out that a well-planned, learnercantered, and authentic e-learning environment prepares learners for working life.

\section{Planning and implementation of the study module}

The development of a new pedagogical education model began with defining pedagogical and technical issues in January 2014, and the work went on for the entire year. The basis for planning was the contextual-pedagogical learning approach [22] which emphasizes transversal competences (pedagogical, substance, and 21st century teaching and citizenship skills) as part of a teacher's pedagogical abilities. Planning the study module was guided by Curriculum content and performance descriptions, which helped outline pedagogically legitimate, authentic learning tasks to achieve curriculum objectives. The objectives were not only content-related, but also transversal competencies and generic skills were included.

The e-learning environment included several elements, through which the learning process became visible. Table 2. presents the connections between the learning tasks and performance descriptions. Students were given instructions for each task of the learning process on the course web pages, as well as provided with examples from earlier years' plans, instructions for making presentations, iPad applications, instructions for AC meeting rooms, and current and related articles to deepen the study module's theoretical framework.

Table 2. Contextual-pedagogical e-learning environment

\begin{tabular}{|c|c|c|}
\hline $\begin{array}{l}\text { Curriculum } \\
\text { contents }\end{array}$ & Learning tasks & $\begin{array}{l}\text { Performance } \\
\text { descriptions }\end{array}$ \\
\hline $\begin{array}{l}\text { Planning a } \\
\text { Basic education } \\
\text { curriculum - } \\
\text { based, } \\
\text { contextual and } \\
\text { experienceful } \\
\text { learning whole } \\
\text { with } \\
\text { interdisciplinary } \\
\text { integration }\end{array}$ & $\begin{array}{l}\text { Writing a } \\
\text { project plan } \\
\text { according to } \\
\text { given } \\
\text { instruction } \\
\text { Familiarising } \\
\text { oneself with } \\
\text { articles, } \\
\text { discussing } \\
\text { concepts, } \\
\text { making } \\
\text { comments } \\
\text { (web } \\
\text { discussions) } \\
\text { Carrying out } \\
\text { and } \\
\text { documenting } \\
\text { the project }\end{array}$ & $\begin{array}{l}\text { Perceives Basic } \\
\text { education } \\
\text { curriculum from } \\
\text { the viewpoint of } \\
\text { interdisciplinary } \\
\text { integration }\end{array}$ \\
\hline $\begin{array}{l}\text { Networking, } \\
\text { cooperation, } \\
\text { internationality, } \\
\text { and shared } \\
\text { expertise in } \\
\text { planning and } \\
\text { implementation } \\
\text { of the learning } \\
\text { whole }\end{array}$ & $\begin{array}{l}\text { Choosing the } \\
\text { class of } \\
\text { pupils for the } \\
\text { project } \\
\text { Presenting } \\
\text { the class and } \\
\text { the learning } \\
\text { environment } \\
\text { (web } \\
\text { discussion) } \\
\text { Creating and } \\
\text { updating a } \\
\text { blog } \\
\text { throughout } \\
\text { the project } \\
\text { Familiarising } \\
\text { the teacher } \\
\text { of the project } \\
\text { class with } \\
\text { the project }\end{array}$ & $\begin{array}{l}\text { Expands his/her } \\
\text { concept of } \\
\text { learning } \\
\text { environment to } \\
\text { include versatile } \\
\text { contextual } \\
\text { environments }\end{array}$ \\
\hline $\begin{array}{l}\text { Expanding } \\
\text { learner-centred } \\
\text { pedagogy into } \\
\text { the surrounding } \\
\text { society }\end{array}$ & $\begin{array}{l}\text { - Pitching the } \\
\text { project and } \\
\text { working as } \\
\text { an opponent } \\
\text { Planning and } \\
\text { arranging a } \\
\text { pedagogical } \\
\text { afternoon, } \\
\text { reporting it } \\
\text { in a blog } \\
\text { Writing a } \\
\text { press release } \\
\text { and } \\
\text { arranging a } \\
\text { press } \\
\text { conference }\end{array}$ & $\begin{array}{l}\text { Applies } \\
\text { innovative } \\
\text { teaching } \\
\text { methods in } \\
\text { planning and } \\
\text { implementation } \\
\text { of teaching }\end{array}$ \\
\hline
\end{tabular}


The six credits' study module was carried out during a period of three months, during which all students and teachers got together in an e-learning space several times in different, authentic, learning situations. Holmes and Gardner [10] link learning with the concept communal constructivism, which describes the student's role not only as an active knowledge builder alone and in cooperation with others, but also as an active developer of information for oneself and the community of learners that he is a part of. When planning the study module we paid great attention to the contents and implementation of the web based learning situations. Web seminars made use of the flipped classroom strategy, so that the students were well prepared for the e-meetings, and it was possible to share and deepen knowledge in a versatile and multi-channel way.

Authentic learning criteria, according to Herington, Reeves and Oliver [8], were used to planning, implementing and assessing the project as a whole. The following table (see Table 3.) describes how the 6 ECTS credits learning course proceeded from the kick off seminar to conclusion seminar and how the ubiquitous, authentic learning and online contact learning was blended to express a contextual pedagogical learning environment as explained in this article. The study module was possible to carry out ubiquitously in authentic learning environments outside the university. Four seminars were organized as webinars with all the students and two teachers on-line at the same time. Peer-interaction was made possible with several different digital solutions and teacher students could choose the best apps, networks and collaboration tools they found reasonable at the time.

The learning task as a whole was to plan, implement and assess a contextual-pedagogical learning project with teachers and students around Finland in primary school contexts in between March and May 2015.

Table 3. The 6 ECTS -course proceeding process

\begin{tabular}{|l|}
\hline MARCH 2015 \\
\hline CONTACT TEACHING ONLINE four hours \\
\hline Project Kick off online \\
Orientation, Grouping, learning module introduction, \\
brainstorming \\
\hline UBIQUITOUS LEARNING six hours \\
Contacting different primary schools to find a suitable \\
co-operation class for this project. Introducing the class, \\
teacher, school and learning environment to other \\
students in web-based learning environment. \\
\hline UBIQUITOUS LEARNING 30 hours \\
\hline Creating a project blog \\
\hline Reading some articles, sharing ideas about them in chat \\
\hline
\end{tabular}

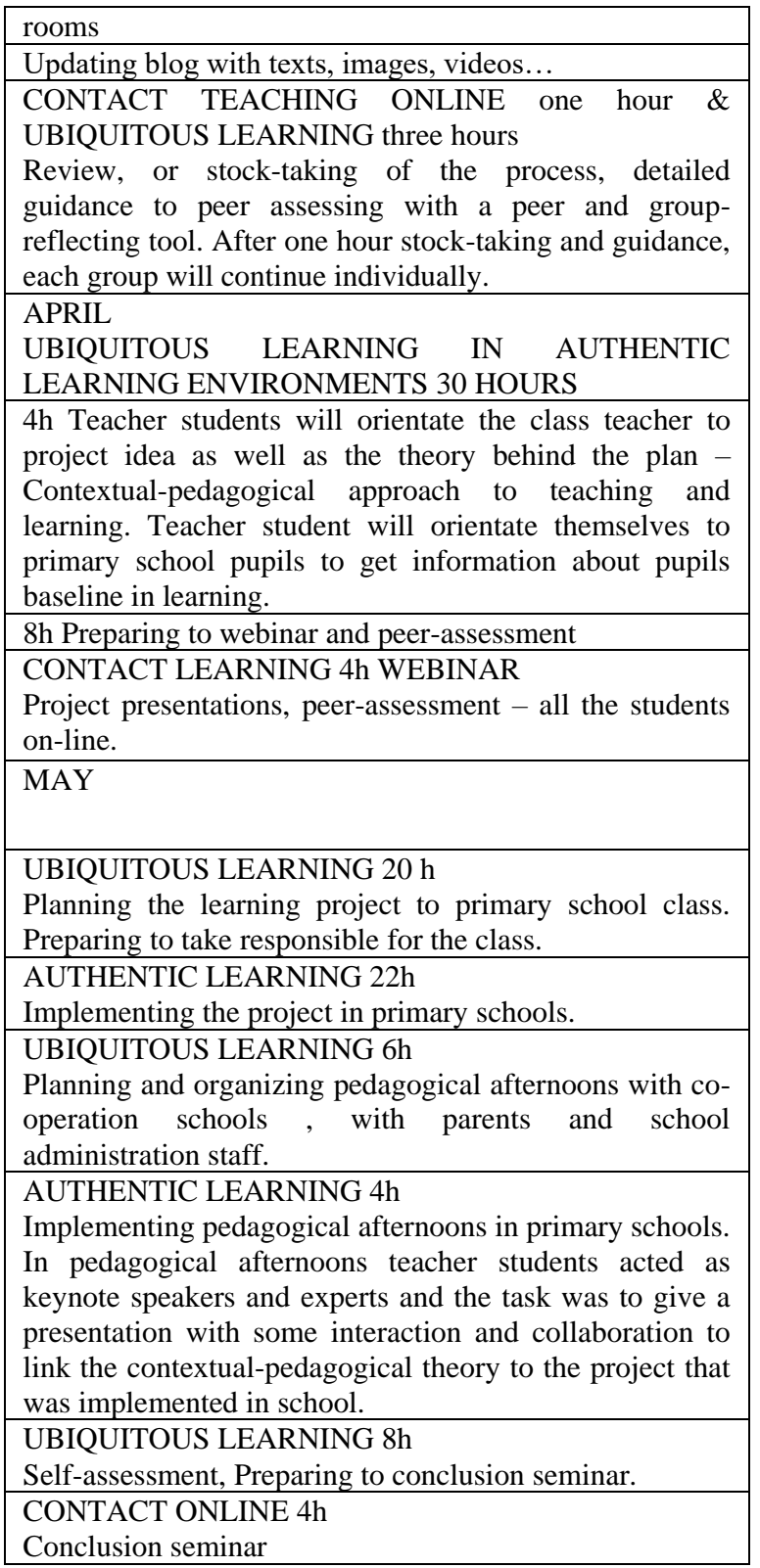

It was crucial to define right in the beginning of the course planning process what are the main knowledge and skills students should achieve during the course and what kind of learning environments would make learning possible at its best. In addition to these questions it was important to perceive what extra value ubiquitous learning would bring to learning.

One of the central aims in this learning module was to develop student's digital skills. Because of that, it was essential to define right in the beginning of the planning process, the main equipment and networks that would be used as well as the apps and web-based environments that would serve learning, communication and collaboration best in the learning processes. 
It was essential that the learning whole would signify transformational pedagogy where digitality would act as a tool for authentic learning.

As most of the study module was carried out ubiquitously, according to the student groups' own schedules, the students had to take responsibility all of their learning. An authentic learning task that guided the students to plan and implement a contextual-pedagogical project with a group of pupils, their teacher, and the school staff, engaged the students to the learning process and the responsibility of one's own learning was taken quite naturally as the project proceeded from one phase to another [25] as presented in Table 4.

Table 4. Contextual-pedagogical tasks of the study module

\section{$4 \mathrm{~h}$}

Familiarise the class teacher with the contextualpedagogical approach and ideology. Material for this is provided on the course web pages. Get to know the pupils in the class and find out their interests and inspiration and the levels of knowledge and skills needed in the project.

$8 \mathrm{~h}$

Prepare well for the web seminar. Create a multi-channel presentation of your project and plan a pitching of the project plan according to the collegial reflection schedule. Send your presentation to the opponent group by the scheduled date. The opponent group: prepare for your task well according to given instruction.

$6 \mathrm{~h}$

Arrange a pedagogical afternoon (or a parents' evening) in the school. The target group may be teachers or some other suitable group. Your task is to work as an expert and promote contextual-pedagogical culture among the target group. You can choose your approach to the pedagogical afternoon.

Tips from earlier courses:

- Activating Apps training in contextualpedagogical framework

- $\quad$ Presenting an implemented project

The duration of the event is $2 \mathrm{~h}$. Document the event in a suitable way in your blog.

Biggs [1], [2] emphasizes that pedagogically good, legitimate planning consists of perfect consistency between curriculum contents and performance descriptions, chosen methods and learning assignments, learning environments, and assessment. The objective of planning the study module presented in this article was to plan a pedagogically sensible learning environment that is independent of time and place and enables achieving the learning objectives of the study module for every student in the best way possible. This can be seen in the discussion between the teachers:

These are the important words that guide the planning: PEDAGOGICALLY SENSIBLE
LEARNING ENVIRONMENT, plus motivated adult students. Can you think of anything else? -A pedagogical manuscript is important, and the whole study module, and all the paths and oasis that are linked into it, must be explained and described clearly so that everybody knows what is expected of them. -Did you notice that nobody has said anything about technology - I would have expected it to have a bigger role in this discussion. -Well yes, it does play a part in distance learning, but one should not get stuck to it when planning a study module.

Biggs' [1], [2] ideas about planning a highquality learning process confirms that the teacher's responsibility is to plan the learning assignments so that a student can show his performance by committing to the assignments, whether the learning environment is a classroom, an online environment, a mixture of these two, or ubiquitous, as described in this article. Dillon et al. [5] describe learning that happens in an e-learning environment with open and closed development paths: formal and authentic learning that happens in the moment can be planned so that it is a closed, strictly defined, and uniform learning path, or, as in the study module presented in this article, it can be planned so that authentic learning assignments enable an individual and communal learning path that opens new perspectives and ideas.

\section{Conclusion}

As a conclusion, this research has clearly pointed out, how both the pedagogical and content aims will be achieved in ubiquitous, authentic learning environments when planning and implementing is based on strong theoretical framework. The main elements in this case were co-planning and co-teaching as a model of transformational teacher hood, well-structured pedagogical plan to support deep learning based on contextual-pedagogical framework, technical choices that fit in the pedagogical framework and finally good commitment of both teachers and preservice teacher to this learning module.

The possibilities Internet provides may at first chain one's thinking and narrow down options in implementation. Collegial cooperation helps change the focus away from technical things, and flexible learning help achieve curriculum performance objective at least as well as teaching that happens physically in the same place. A successful study module needs a good manuscript and a clear timetable that each participant commits to. Co-planning and sharing expertise openly are possibilities of university education. 
According to the feedback from Class teacher adult education students they look for more possibilities for distance learning, and that the good methods that have been used during the on-going project period would be used more. In addition, providing the students with personal, modern technology in the beginning of studies enables the expansion of learning environments outside classrooms. If teachers' work does not change, education does not change. Independent, motivated and highly educated teachers are the heroes behind Pisa success. Finnish teachers have great autonomy and power to decide what and how they teach. A part of the teachers are enthusiastic and passionate about learning new things and they also develop teaching and learning boldly. But teachers' autonomy also enables them to close the classroom door and go on as if nothing in the world had changed. That may end up with great differences between schools and classes. Some teachers use technology, experiment new assessment methods and give up on desks. Others stick to the old ways. [12]

-This is the core of the whole thing: it does not make a difference in learning where we are and when, the point is, like you just said, how learning is made possible and planned so that it is possible to achieve the objectives in a sensible way.

\section{References}

[1] Biggs. J. (1999) Teaching for Quality Learning at University - What the Student Does (1st Edition) SRHE / Open University Press, Buckingham.

[2] Biggs. J. (2003) Teaching for Quality Learning at University - What the Student Does 2nd Edition SRHE / Open University Press, Buckingham.

[3] Bonk, C. J., Kim, K. J., \& Zeng, T. (2006). Future directions of blended learning in higher education and workplace learning settings. In C. J. Bonk \& C. R. Graham (Eds.). Handbook of blended learning: Global Perspectives, local designs (pp. 550-567). San Francisco, CA: Pfeiffer Publishing.

[4] Cavallo, D., Stager, D., Papert S. 2004. Climbing to Understanding: Lessons from an Experimental Learning Environment for Adjudicated Youth. In Proceedings from International Conference of the Retrieved 8.5.2014. Learning Sciences, California, USA, June, pp. 113120, 2004.

[5] Dillon, P., Wang, R., Vesisenaho, M., Valtonen, T. \& Havu-Nuutinen, S. 2011. Using technology to open up learning and teaching through improvisation: Case studies with micro-blogs and short message service communications. Thinking Skills and Creativity. 10; 13-22.

[6] Halinen, I. 2014. Curriculum Reform in Finland. Online presentation 8.1.2014. Kokkola University Consortium Chydenius.

[7] Hammerness, K., Darling-Hammond, L., Bransford, J., Berliner, D., Cochran-Smith, M., McDonald, M. \& Zeichner, K. 2007. How teachers learn and develop. Teoksessa: Darling-Hammond, L. \& Bransford, J. 2007. Preparing Teachers for a Changing World. What Teachers Should Learn and Be Able to Do? National Academy of Education. $358-389$.

[8] Herrington, J., Reeves, T. C. \& Oliver, R. 2010. A guide to authentic e-learning. New York: Routledge.

[9] Hodges, C. B. \& Repman, J. (2011). Moving outside the LMS: Matching Web 2.0 tools to instructional purpose. EDUCAUSE Learning Initiative, September.http://net.educause.edu/ir/libr ary/pdf/ELIB1103.pdf

[10] Holmes, B. \& Gardner, J. 2011. E-learning: concepts and practice. Researh in Teacher Education. Vol 1:2.

[11] Honkonen, S. 2015. Teknologiassa ei ole kyse koneista vaan ihmisistä. Teoksessa Maa, jossa kaikki rakastavat oppimista. Sitra. Erweko Oy, Helsinki 2015.

[12] Impiö, P., Meriläinen, M., \& Piispanen, M. 2015. Ajasta ja paikasta riippumatta. Konferenssiesitys. Tulevaisuus haastaa oppimisen ja verkko-opettajan. Jyväskylän yliopisto.

[13] Kiviniemi, K., Leppisaari, I. \& Teräs, H. 2013. Autenttiset verkko-oppimisratkaisut asiantuntijuuden kehittäjinä. Teoksessa J. T. Hakala \& K. Kiviniemi (toim.) Vuorovaikutuksen jännitteitä ja oppimisen säröjä.

[14] Lambert, J., Cuper, P. 2008. Multimedia technologies and familiar spaces: 21stcentury teaching for 21 st century learners. Contemporary Issues in Technology and Teacher Education, 8(3).

[15] Leinonen, T. Opettaja ei saa tehdä työtään yksin. Teoksessa Maa, kossa kaikki rakastavat oppimista. Sitra. Erweko Oy, Helsinki 2015.

[16] Leppisaari, I. 2014. Pedagogisella vertaiskehittämisellä avoimia, autenttisia ja yhteisöllisiä oppimisympäristöjä Virtuaaliam- 
mattikorkeakouluverkostossa. AMK-lehti //Journal of Finnish Universities of Applied Sciences, No 1 (2014) Issues in Educational Research, 23(2), 2013 Special Issue 227. Authentic online learning: Aligning learner needs, pedagogy and technology. Jenni Parker, Dorit Maor and Jan Herrington. Murdoch University.

[17] Leppisaari, I., Herrington, J., Vainio, L. \& Im, Y. 2013. Authentic e-Learning in a Multicultural Context: Virtual Benchmarking Cases from Five Countries. Journal of Interactive Learning Research, 24(1), 53-73. Chesapeake, VA: AACE.

[18] Leppisaari, I., Ihanainen, P., Nevgi, A., Taskila, V-M., Tuominen, T. \& Saari, S. (2008). Hyvässä kasvussa - Yhdessä kehittäen kohti ammattikorkeakoulujen laadukasta verkkoopetusta. Korkeakoulujen arviointineuvoston julkaisuja 4: 2008. Helsinki. http://www.kka.fi/ files/384/KKA_408.pdf.

[19] Leppisaari, I., Meriläinen, M., Piispanen, M. \& Pulkkinen, A. 2015. Päivitä opettajuus digiaikaan - PODkehittämistehtävät tukemassa oppimiskulttuurin uudistumista. Teoksessa (toim.) Viteli, J. \& Östman, T. Tuovi 13: Interaktiivinen tekniikka koulutuksessa 2015-konferenssin tutkijatapaamisen artikkelit. Research Reports 15.

[20] Maor, D. (2003). Teacher's and students' perspectives on on-line learning in a social constructivist learning environment. Technology, Pedagogy and Education, 12(2), 201218.http://dx.doi.org/210.1080/1475939030020015 4.

[21] Mayring, P. 2000. Qualitative Content Analysis.Vol.1. No 2. June 2000. Forum Qualitative Social research. http://www.utsc. utoronto.ca/ kmacd/IDSC10/Readings/text\%20ana lysis/CA.pdf.

[22] Meriläinen, M. \& Piispanen, M. 2012. Learning as a Phenomenon - Manuscript of Phenomenon Based Learning. Toim: L. Gómez Chova, A. López Martínez, I. Candel Torres. Edulearn12: 4th International Conference on Education and New Learning Technologies 5447-5454).

[23] Oliver, R. 2005. Quality assurance and elearning: blue skies and pragmatism. Alt-J, 13 (3), 2005; 173-187. http://dx.doi.org/10.1080/ 09687760500376389.

[24] Lombardi, M.M. (2007). Approaches that work: How authentic learning is transforming higher education. ELI Report No 5. Boulder, CO: EDUCAUSE Learning Initiative.

[25] Piispanen, M. 2013. Anna mun oppia ja osata! Oppimisen konteksti ja pedagogiikka uudistavan koulun avaimina. In Työ arvonsa ansaitsee, ed. P. Atjonen, 139-154. Oulun yliopisto: Kasvatustieteiden tiedekunnan julkaisuja.

[26] Piispanen, M. \& Meriläinen, M. 2015. Assessment as a Possibility for Individual

Learning and Success in Contextual Pedagogical Learning Environment. International Journal for Cross-Disciplinary Subjects in Education (IJCDSE), Volume 6, Issue 4; 2312 - 2321, December 2015.

[27] Piispanen, M. \& Meriläinen, M. 2013. Phenomenon Called Learning! - Turning Learning from Traditional to Transformational. 15th Annual International Conference on Education. The Education Research Unit of ATINER.

[28] Puentedura, R. 2010. SAMR and TPCK: Intro to advanced practice. http://hippasus.com/reso urces/sweden2010/SAMR_TPCK_IntroToAdvance dPractice.pdf.

[29] Purser, E., Towndrow, A. \& Arangui, A. (2013). Realising the Potential of Peer-to-Peer Learning: Taming a MOOC with Social Media. Retrieved 16.10.2013 from http://www.openeducationeuropa.eu/en/?

[30] Reeves,T., Heerington, J., Oliver. R. 2002.Authentic Activities and On-line Learning. Herdsa. 2002. p.562-567.

[31] Rotherham, A. J., \& Willingham, D. 2009. To work, the 21st century skills movem Authentic Activities andent will require keen attention to curriculum, teacher quality, and assessment. Educational Leadership, 9, 15-20.

[32] Rule, A. C. 2006. The components of authentic learning. Journal of Authentic Learning, 3(1), 1-10.

[33] Teräs, H., Leppisaari, I., Teräs, M. \& Herrington, J. 2014. Learning cultures and multiculturalism: Authentic e-learning designs. In T. Issa, P. Isaias \& P. Kommers (Eds.) Multicultural Awareness and Technology in Higher Education: Global Perspectives. IGI-Global, 197217. 